\title{
Ciliary Neurotrophic Factor Cell-Based Delivery Prevents Synaptic Impairment and Improves Memory in Mouse Models of Alzheimer's Disease
}

\author{
Pierre Garcia, ${ }^{1 \star}$ Ihsen Youssef, ${ }^{1 *}$ Jo K. Utvik, ${ }^{2}$ Sabrina Florent-Béchard, ${ }^{1}$ Vanassa Barthélémy, ${ }^{2}$ \\ Catherine Malaplate-Armand, ${ }^{1,4}$ Badreddine Kriem, ${ }^{1}$ Christophe Stenger, ${ }^{1}$ Violette Koziel, ${ }^{1}$ Jean-Luc Olivier, ${ }^{1,4}$ \\ Marie-Christine Escanye, ${ }^{1,4}$ Marine Hanse, ${ }^{1}$ Ahmad Allouche, ${ }^{1}$ Cédric Desbène, ${ }^{1,4}$ Frances T. Yen, ${ }^{1}$ Rolf Bjerkvig, ${ }^{2,3}$ \\ Thierry Oster, ${ }^{1,5}$ Simone P. Niclou, ${ }^{2}$ and Thierry Pillot ${ }^{1}$ \\ ${ }^{1}$ JE2482 Lipidomix, Nancy Université, 54500 Vandoeuvre, France, ${ }^{2}$ NorLux Neuro-Oncology Laboratory, Centre de Recherche Public-Santé, L-1526 \\ Luxembourg, ${ }^{3}$ NorLux Neuro-Oncology, Department of Biomedicine University of Bergen, N-5020 Bergen, Norway, ${ }^{4}$ Department of Biochemistry, \\ University Hospital, F-54000 Nancy, France, and ${ }^{5}$ Unité de Formation et de Recherche, Sciences Fondamentales et Appliquées, Université Paul Verlaine, \\ 57000 Metz, France
}

The development of novel therapeutic strategies for Alzheimer's disease (AD) represents one of the biggest unmet medical needs today. Application of neurotrophic factors able to modulate neuronal survival and synaptic connectivity is a promising therapeutic approach for $\mathrm{AD}$. We aimed to determine whether the loco-regional delivery of ciliary neurotrophic factor (CNTF) could prevent amyloid- $\beta$ (A $\beta$ ) oligomer-induced synaptic damages and associated cognitive impairments that typify AD. To ensure long-term administration of CNTF in the brain, we used recombinant cells secreting CNTF encapsulated in alginate polymers. The implantation of these bioreactors in the brain of A $\beta$ oligomer-infused mice led to a continuous secretion of recombinant CNTF and was associated with the robust improvement of cognitive performances. Most importantly, CNTF led to full recovery of cognitive functions associated with the stabilization of synaptic protein levels in the Tg2576 AD mouse model. In vitro as well as in vivo, CNTF activated a Janus kinase/signal transducer and activator of transcription-mediated survival pathway that prevented synaptic and neuronal degeneration. These preclinical studies suggest that CNTF and/or CNTF receptor-associated pathways may have AD-modifying activity through protection against progressive $\mathrm{A} \beta$-related memory deficits. Our data also encourage additional exploration of ex vivo gene transfer for the prevention and/or treatment of AD.

\section{Introduction}

The progressive impairment of short-term memory and emotional disturbances that typify Alzheimer's disease (AD) results from synaptic dysfunction and death of neurons in the hippocampus and associated regions of the cerebral cortex and limbic system (Selkoe, 2002; Scheff et al., 2007). These abnormalities are believed to result from interactions of soluble amyloid- $\beta$ $(\mathrm{A} \beta$ ) oligomers with synaptic plasma membranes (Walsh et al., 2002; Sponne et al., 2003; Lacor et al., 2004; Kokubo et al., 2005). Consequently, several of the current therapeutic strategies specifically address the amyloid pathology in AD brain (Klafki et al., 2006). These approaches have been designed to decrease the production of $\mathrm{A} \beta$ by the use of so-called specific secretase inhibitors,

Received Aug. 25, 2009; revised March 29, 2010; accepted April 2, 2010.

This work was supported by the Fonds National de la Recherche of Luxembourg, the Région Lorraine, the Ligue Européenne Contre la Maladie d'Alzheimer (France), the Fondation pour la Recherche sur le (erveau (France), the Alzheimer Moselle Nord Association (France), the Alzheimer 54 Association (France), and the France Alzheimer Meurthe et Moselle (France). We thank E. Magueur for technical expertise.

*P.G. and I.Y. contributed equally to this work.

The authors have no conflicting financial interests.

Correspondence should be addressed to Dr. Thierry Pillot, EA4422 Lipidomix, Nancy Université, 2 avenue de la Forêt de Haye, F-54505 Vandœuvre-lès-Nancy, France. E-mail: thierry.pillot@ensaia.inpl-nancy.fr.

DOI:10.1523/JNEUROSCI.4182-09.2010

Copyright $\odot 2010$ the authors $\quad 0270-6474 / 10 / 307516-12 \$ 15.00 / 0$ whereas others attempt to induce $\mathrm{A} \beta$ clearance using $\mathrm{A} \beta$ immunotherapy (Selkoe, 2004). It is noteworthy that all of these approaches aim primarily toward reducing $\mathrm{A} \beta$ peptide levels in the brain. However, although no physiological function has been ascribed to the $\mathrm{A} \beta$ monomer itself, marked or complete depletion of monomers could result in side effects (Puzzo et al., 2008). In addition, these strategies do not rescue neurons already compromised by $\mathrm{A} \beta$-induced stress responses. There is therefore an urgent need to develop strategies able to interfere with disease progression to halt ongoing cognitive decline.

The major role of neurotrophic factors (NTFs) in synapse function (Vicario-Abejon et al., 2002) along with evidence that synaptic failure is a critical early event in AD (Selkoe, 2002) has put NTFs at the forefront of neuroprotective strategies for AD (Blesch, 2006). Recent studies suggest that changes in NTF homeostasis may contribute to neuronal degeneration in AD (Twiss et al., 2006). Nerve growth factor and brain-derived neurotrophic factor improve memory in AD models (Tuszynski, 2007). However, the application of NTFs as therapeutic agents for AD faces limitations, including limited blood-brain barrier permeability (Allen and Dawbarn, 2006). To overcome these problems, NTFs can be delivered directly to the brain by implantation of cells engineered to produce NTFs (Tuszynski et al., 2002). To prevent 
an inflammatory reaction in the brain or the destruction of the transplanted cells by immune cells, the producer cells can be encapsulated in various encapsulation devices. This strategy has been successfully developed in different experimental models of brain diseases, such as Huntington disease (Emerich et al., 1996), Parkinson disease (Frim et al., 1994), AD (Tuszynski et al., 1998), and brain tumors (Read et al., 2001).

Ciliary neurotrophic factor (CNTF) belongs to the interleukin-6 family of cytokines and is known for its neuroprotective effects, being a survival factor for sympathetic, sensory, and hippocampal neurons. Although CNTF protects neurons from degeneration arising from multiple etiologies (Duff and Baile, 2003; Sieving et al., 2006), it has not been evaluated in preclinical studies in the context of AD pathology (Emerich and Thanos, 2006). Here, we show that CNTF continuously delivered from microcapsule containing engineered CNTF cells implanted in the brain of two $\mathrm{AD}$ mouse models prevents $\mathrm{A} \beta$ oligomer-induced neuronal damage and neurobehavioral impairments. We further show that CNTF action requires the Janus kinase/signal transducer and activator of transcription (JAK/STAT) and phosphatidylinositol 3-kinase (PI3K) signaling pathways.

\section{Materials and Methods}

\section{Recombinant cell production and alginate bead encapsulation}

The $\mathrm{C} 2 \mathrm{C} 12$ myoblast cell line (kindly provided by P. Aebischer, Lausanne, Switzerland) stably expressing human CNTF (hCNTF) was grown in DMEM supplemented with $10 \%$ fetal calf serum (FCS), $100 \mathrm{U} / \mathrm{ml}$ penicillin plus $100 \mathrm{U} / \mathrm{ml}$ streptomycin ( $1 \times \mathrm{PS}), 2 \mathrm{~mm}$ glutamine (Gln), and $1 \times$ nonessential amino acids (NEAA). To allow direct visualization of the capsules in vitro and in vivo, both the control and the CNTFproducing cells lines were genetically engineered by lentiviral vector transduction to express the fluorescent marker protein enhanced green fluorescent protein (eGFP). For encapsulation in alginate, the producing cells were harvested, counted, and mixed into a $2 \%$ sodium alginate (ultrapure, low viscosity, high guluronic acid content; PRONOVA UP LVG, NovaMatrix; FMC BioPolymer) saline solution $[0.9 \% \mathrm{NaCl}$ and 10 mм 3-(N-morpholino)-propanesulfonic acid (MOPS), pH 7.4] at a concentration of $50 \times 10^{6}$ cells $/ \mathrm{ml}$ alginate solution. Alginate beads were generated with an electrostatic bead generator (Read et al., 2001). To obtain small-sized beads (100-200 $\mu \mathrm{m})$, sharpened nozzles with a diameter of $0.17 \mathrm{~mm}$ were used (Nisco Engineering). The gelling bath was composed of $0.1 \mathrm{M} \mathrm{CaCl}_{2}$ in $0.9 \% \mathrm{NaCl}$ with $10 \mathrm{~mm}$ MOPS, pH 7.4. After encapsulation, beads containing $500-1000 \mathrm{C} 2 \mathrm{C} 12$ cells were washed and kept in culture medium (CM) until use. CNTF secretion from the beads was verified by immunoblot analysis and ELISA.

\section{Primary cell cultures and treatments}

Primary cultures of C57BL/6 mouse neurons were prepared as described previously (Sponne et al., 2003; Fifre et al., 2006). Neurons were treated at $8-10 \mathrm{~d}$ in vitro (DIV) with increasing concentrations of soluble $\mathrm{A} \beta$ oligomers for the indicated times. Alternatively, cells were preincubated for $2 \mathrm{~h}$ under the indicated conditions before addition of $A \beta$ oligomers. $\mathrm{A} \beta_{1-40}$ and $\mathrm{A} \beta_{1-42}$ were obtained from Bachem, and soluble oligomers of $\mathrm{A} \beta$ were prepared as described previously (Pillot et al., 1999; Fifre et al., 2006; Youssef et al., 2008). Oligomeric preparations of $A \beta$ resolve to monomers, trimers, and tetramers $(15-20 \mathrm{kDa})$ after SDS-PAGE, as described previously (Dahlgren et al., 2002; Malaplate-Armand et al., 2006; Puzzo et al., 2008; Youssef et al., 2008). Unless otherwise indicated, materials used for cell culture were obtained from Invitrogen.

\section{Neuronal viability and monitoring of apoptosis}

Cell viability was assessed using the release of lactate dehydrogenase and the 3-(4,5-dimethylthiazol-2-yl)-2,5-diphenyltetrazolium bromide (MTT) assays as described previously (Kriem et al., 2005; Youssef et al., 2008). Alternatively, cell viability was monitored using a LIVE/DEAD Viability/ Cytotoxicity kit (Invitrogen) according to the recommendations of the manufacturer. Cell nuclei were visualized using 4,6-diamidino-2-phenylindole (DAPI) (Sponne et al., 2003). To evaluate the percentage of apoptotic cells, 14 independent fields from four wells were analyzed (>1000 cells per group). Caspase activities were measured by following the cleavage of the substrates Ac-DEVD-AMC (7-amino-4-methylcoumarin, $\mathrm{N}$-acetyl-Laspartyl-L-glutamyl-L-valyl-L-aspartic acid amide) and Ac-LEHD-AMC (acetyl-Leu-Glu-His-Asp-7-amino-4-methylcoumarin) using previously described procedures (Sponne et al., 2003). Fifty micrograms of cellular proteins were incubated for $2 \mathrm{~h}$ with $100 \mu \mathrm{M}$ caspase substrates from a stock solution of $10 \mathrm{~mm}$ in DMSO. The cleavage of the caspase substrates was monitored by fluorescence emission at $460 \mathrm{~nm}$ after excitation at $360 \mathrm{~nm}$, using a Fluostar microplate reader (BMG-Labtechnologies).

\section{Immunoblot analyses}

Mouse primary neurons cultured under different conditions were washed with ice-cold PBS. Cells were then solubilized in a $25 \mathrm{~mm}$ Tris$\mathrm{HCl}, \mathrm{pH} 7.4$, lysis buffer containing $150 \mathrm{~mm} \mathrm{NaCl}, 1 \mathrm{~mm}$ EDTA, $1 \%$ (w/v) sodium deoxycholate, $1 \%(\mathrm{v} / \mathrm{v})$ Nonidet P-40, $0.1 \%(\mathrm{w} / \mathrm{v})$ SDS, and protease inhibitors (Complete; Roche). After homogenization, collected cells were then lysed using three cycles of freezing and thawing and finally centrifuged at $4^{\circ} \mathrm{C}$ for $10 \mathrm{~min}$ at $10,000 \times \mathrm{g}$. Protein concentration in the supernatant was determined by BCA Protein Assay kit (Interchim). Samples $(10 \mu \mathrm{g})$ were mixed with an equal volume of $2 \times$ Laemli's buffer, denatured by heating the mixture for $5 \mathrm{~min}$ at $100^{\circ} \mathrm{C}$.

Synaptosomal membrane fractions were prepared as described previously (Keller et al., 1997). Briefly, brain regions were dissected and rapidly homogenized in ice-cold $10 \mathrm{~mm}$ Tris buffer, $\mathrm{pH}$ 7.4, containing 0.32 mM sucrose, 2 mM EDTA, $10 \mu \mathrm{g} / \mathrm{ml}$ sodium orthovanadate, and protease inhibitors ( $1 \mathrm{~mm}$ phenylmethylsulfonyl fluoride, $10 \mu \mathrm{g} / \mathrm{ml}$ leupeptin, 10 $\mu \mathrm{g} / \mathrm{ml}$ pepstatin, and $5 \mu \mathrm{g} / \mathrm{ml}$ aprotinin). The homogenate was spun at $1000 \times g$ for $15 \mathrm{~min}$ to remove nuclei and cell debris. The resulting supernatant was centrifuged at $12,000 \times g$ for $20 \mathrm{~min}$ to obtain the synaptosomal preparation.

Samples (conditioned medium from $\mathrm{C} 2 \mathrm{C} 12$ cell capsules, cell extracts, or synaptosomes) were then subjected to SDS-PAGE and immunoblotting. The following antibodies were used: CNTF (1:500 dilution; Sigma); MAP2 (1:500 dilution; Santa Cruz Biotechnology); calpain regulatory subunit (1:500 dilution; Santa Cruz Biotechnology); caspase-3 (1:500 dilution; Santa Cruz Biotechnology); actin (1:1000 dilution, C-11 antibody; Santa Cruz Biotechnology); Akt and phosphorylated (P) Akt$\left(\right.$ Ser $\left.^{473}\right)$ (1:1000 dilution; Cell Signaling Technology); P-cAMP response element-binding protein (CREB) $\left(\operatorname{Ser}^{133}\right)$ (1:500 dilution; Cell Signaling Technology), GluR1 and GluR2/3 (1:500 dilution; Millipore Bioscience Research Reagents); STAT3 and P-STAT3 $\left(\mathrm{Tyr}^{705}\right)$ (1:500 dilution; Santa Cruz Biotechnology); JAK-1 and P-JAK-1(Y1022) (1:500 dilution; Santa Cruz Biotechnology); PSD95 (1:500 dilution; Cell Signaling Technology); amyloid precursor protein (APP) (1:1000 dilution, 22C11 antibody; Millipore Corporation); $\beta$-tubulin (1:1000 dilution; Santa Cruz Biotechnology); synapsin (1:1000 dilution; Millipore Corporation); SNAP25 (1:2000 dilution; Santa Cruz Biotechnology); synaptotagmin (1:1000 dilution; Calbiochem); stargazin (1:500 dilution; Cell Signaling Technology); and synaptophysin (1:500 dilution; Millipore Bioscience Research Reagents). Immunoblots were probed with the corresponding horseradish peroxidase-conjugated preadsorbed secondary antibodies (1:2000 dilution; Cell Signaling Technology) and detected using the enhanced chemiluminescence protocol (ECL kit; GE Healthcare). The QUANTITY ONE software, associated with VersaDoc Imaging System (model 1000; Bio-Rad), was used to quantify the protein signals.

\section{Immunocytochemistry}

After treatment, neurons were fixed in PBS containing 4\% (w/v) paraformaldehyde for $30 \mathrm{~min}$ at room temperature. The cells were permeabilized with PBS containing 3\% (w/v) BSA and $0.1 \%(\mathrm{v} / \mathrm{v})$ Triton X-100 for $30 \mathrm{~min}$ at room temperature and then incubated successively with an anti-MAP2 antibody (1:500 dilution) and an Alexa Fluor 488 donkey anti-goat antibody (1:1000 dilution). The microtubule network was 
visualized using a Nikon microscope using a PlanFluor $60 \times / 1.3$ objective, and images were taken using a Nikon DXM1200 digital camera. For semiquantitative analysis of microtubule organization, at least 10 microscope fields per condition were viewed using a Nikon DXM1200 digital camera, and microtubule organization in 50-60 cells per field was classified as normal or disrupted as described previously (Sponne et al., 2003; Fifre et al., 2006).

\section{Mice and surgical procedures}

Mice. Male C57BL/6 mice (12 weeks old) were purchased from Janvier Laboratories. Male mice aged 10 weeks and overexpressing the Swedish APP mutant, Tg (HuAPP695.K670N-M671L) 2576, and their wild-type (WT) littermates were purchased from Taconic (001349-T strain on the C57BL/ $6 \times$ SJL background). Animals were housed five to six per cage with access to food and water ad libitum and were kept in a controlled environment $\left(22 \pm 1{ }^{\circ} \mathrm{C}, 50 \pm 5 \%\right.$ humidity $)$ with a $12 \mathrm{~h}$ light/dark cycle (lights on 7:30 A.M.) and assessed during the light phase.

Surgery. All surgical procedures were performed on anesthetized mice (ketamine-xylazine mix, $1 \mathrm{mg} / 10 \mathrm{~g}$ body weight, i.p.). The animal facilities and all animal procedures were approved by the Animal Care and Veterinary Committee of Meurthe-et-Moselle (Nancy, France).

Alginate bead implantation. C57BL/6 mice ( $n=12$ per group) were implanted at the age of 3 months with a single alginate bead containing $500-1,000$ CNTF-C2C12 or control C2C12 cells using a stereotaxic device. In a control experiment, an empty alginate bead (containing no cells) was implanted using the same experimental procedure. Beads were implanted into the right ventricle [anteroposterior (AP), $-0.22 \mathrm{~mm}$; lateral $(\mathrm{L}),-1 \mathrm{~mm}$; dorsal $(\mathrm{D}),+2.5 \mathrm{~mm}$ ] or above the cornus amonis 1 (CA1) subfield of hippocampus (AP, $+1.75 \mathrm{~mm} ; \mathrm{L},-1.5 \mathrm{~mm}$; D, +1.95 $\mathrm{mm})$. Five-month-old Tg2576 mice ( $n=8$ per group) received two alginate beads per ventricle. Implantations were performed using a $5 \mu \mathrm{l}$ Hamilton syringe (7000 Series Modified Microliter, knurled hub, 24 gauge needle; model 7105). Beads were injected in a total volume of $1 \mu \mathrm{l}$.

Intracerebroventricular injection of soluble $A \beta$ oligomers. Soluble $A \beta_{1-42}$ oligomers were prepared as described above as stock solutions at the concentration of $0.5 \mathrm{~mm}$ in sterile $0.1 \mathrm{M}$ PBS, $\mathrm{pH}$ 7.4, and aliquots were stored at $-20^{\circ} \mathrm{C}$ until use. Three weeks after bead implantation, soluble $\mathrm{A} \beta$ oligomers (50 pmol in $1 \mu \mathrm{l}$ ) or vehicle (saline) were injected into the left ventricle (from bregma: AP, $-0.22 \mathrm{~mm}$;,$+1.0 \mathrm{~mm}$; and $\mathrm{D},+2.5$ $\mathrm{mm})$. Injections were made using a $10 \mu \mathrm{l}$ Hamilton microsyringe fitted with a 26 gauge needle as described previously (Youssef et al., 2008). Alternatively, male C57BL/6 mice $(n=12$ per group) were injected intracerebroventricularly with hCNTF or vehicle. One week later, mice received an intracerebroventricular injection of $50 \mathrm{pmol} \mathrm{A} \beta_{1-42}$ oligomers, as described previously (Youssef et al., 2008).

\section{Behavioral analysis}

$Y$-maze test. Immediate working memory performance was assessed by recording spontaneous alternation behavior in a $\mathrm{Y}$ maze as described previously (Sarter et al., 1988; Youssef et al., 2008). The maze was made of opaque Plexiglas, and each arm was $40 \mathrm{~cm}$ long, $16 \mathrm{~cm}$ high, and $9 \mathrm{~cm}$ wide and positioned at equal angles. Mice were placed at the end of one arm and allowed to move freely through the maze during a 5 min session. The series of arm entries were recorded visually, and arm entry was considered to be completed when the hindpaws of the mouse were completely placed in the arm. Alternation was defined as successive entries into the three arms on overlapping triplet sets. The percentage alternation was calculated as the ratio of actual (total alternations) to possible (defined as the number of arm entries minus two) alternations.

Water-maze test. The water maze was performed as described previously by Morris (1984). The experimental apparatus consisted of a circular water tank (diameter, $80 \mathrm{~cm}$; height, $50 \mathrm{~cm}$ ) containing water at $22^{\circ} \mathrm{C}$ to a depth of $25 \mathrm{~cm}$ and rendered opaque by adding an aqueous acrylic emulsion. A platform (diameter of $10 \mathrm{~cm}$ ) was submerged $1 \mathrm{~cm}$ below the water surface and placed at the midpoint of one quadrant (Youssef et al., 2008). The pool was placed in a test room homogenously brightened at 100 lux and containing various prominent visual cues on the walls. The swimming paths of the animals were recorded using a video tracking system. On days 3 and 4, navigation to a visible platform
A

1 week 8 months

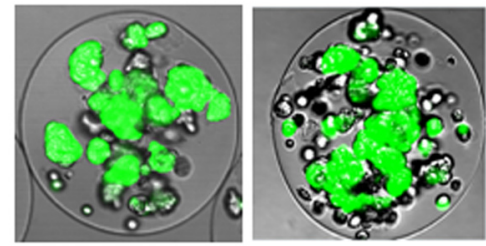

B

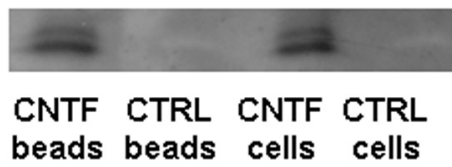

C

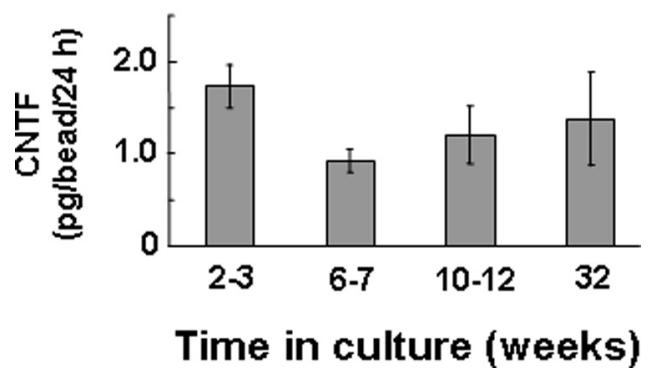

Figure 1. Long-term CNTF secretion from encapsulated C2C12 cells. $\boldsymbol{A}$, Long-term survival of alginate encapsulated CNTF-expressing $\mathrm{C} 2 \mathrm{C} 12$ cells as shown by eGFP expression at 1 week and 8 months in culture. $\boldsymbol{B}$, Immunoblot of conditioned medium from CNTF producing C2C12 capsules and from the corresponding cell monolayer. C, Mean \pm SEM hCNTF secretion per $24 \mathrm{~h}$ from one alginate bead determined by ELISA at different time points in culture $(n=3-9$ per time point).

was performed before place navigation to evaluate visual and motor abilities of the animals. Mice were submitted to four trials per day with two trials in the morning and two trials in the afternoon and with an intertrial interval of at least $45 \mathrm{~min}$. There was no additional maze cue in the room. The platform position and starting points were randomly distributed over all four quadrants of the pool. Mice that failed to find the platform after $60 \mathrm{~s}$ were guided to its location. Next, memory-acquisition trials (training) were performed four times daily during 5 consecutive days to reach a steady state of escape latency. The mice were allowed to swim freely for $60 \mathrm{~s}$, left alone for an additional $30 \mathrm{~s}$ on the hidden platform, and then returned to the home cage during the intertrial interval. The intratrial intervals during four trials were $45 \mathrm{~min}$. Start positions (set at each limit between quadrants) were randomly selected for each animal. In each trial, the time required to escape onto the hidden platform was recorded. Mice failing to find the platform within $60 \mathrm{~s}$ were placed on the platform for $10 \mathrm{~s}$ at the end of the trial. Memory-retention tests (probe trials) were performed $3 \mathrm{~d}$ after the last training session. The platform was removed, and each mouse was allowed a free $60 \mathrm{~s} \mathrm{swim.} \mathrm{The}$ number of crossings over the original platform point, the time required for the first crossing over, and the time spent in each of the four quadrants were measured by analyzing the video recordings.

\section{ELISA}

For $\mathrm{A} \beta$ measurements, a hemibrain region including cortex and hippocampus from Tg2576 mice were dissected, flash frozen in liquid nitrogen, homogenized, and extracted as described previously (McLaurin et al., 2006). Sandwich ELISAs were performed according to recommendations of the manufacturer to quantify total $\mathrm{A} \beta_{1-40}$ and $\mathrm{A} \beta_{1-42}$ using the human $\mathrm{A} \beta_{1-40}$ and $\mathrm{A} \beta_{1-42}$ kits from Covance and Biosource, respectively. To determine the concentration of hCNTF secreted from beads, triplicates of 10 beads were incubated in $500 \mu$ l of medium (DMEM, $10 \%$ FCS, $1 \times$ PS, $2 \mathrm{~mm}$ Gln, and $1 \times$ NEAA) for $48 \mathrm{~h}$. The medium was harvested, and CNTF was measured using an ELISA kit for human CNTF (Quan- 
A

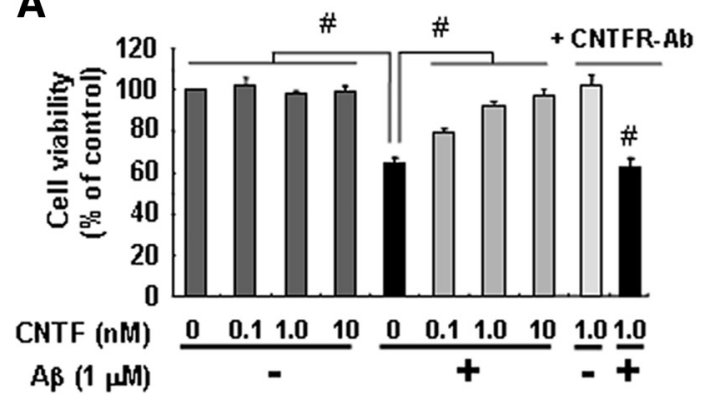

C

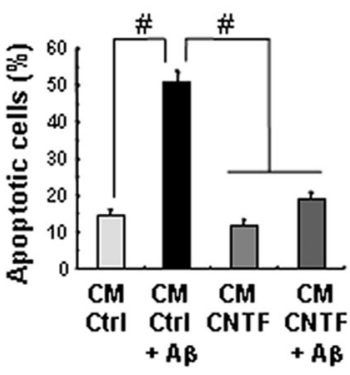

B

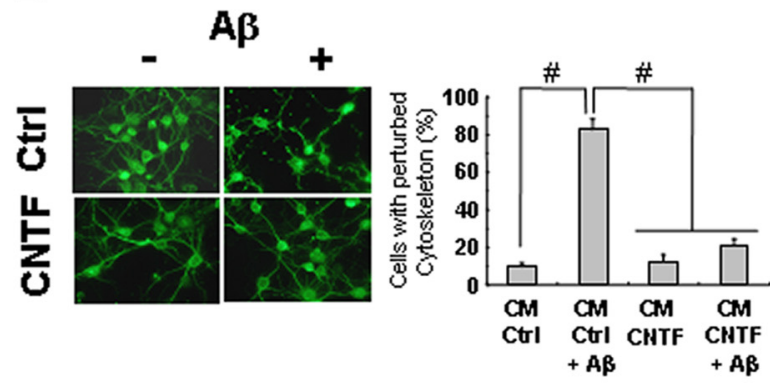

$\mathbf{E}$

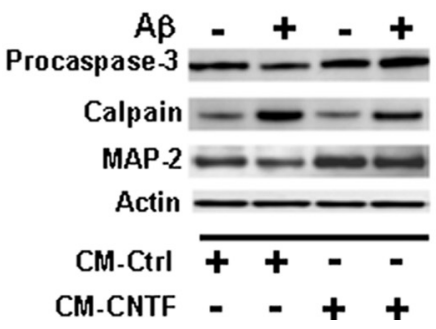

Figure 2. Secreted CNTF prevents A $\beta$ oligomer-induced neurodegeneration in vitro. A, Mouse hippocampal and cortical neurons were preincubated for $2 \mathrm{~h}$ with CM from encapsulated CNTF cells containing the indicated CNTF concentrations or CM from encapsulated control cells in the absence or presence of anti-CNTF receptor antibodies (CNTFR-Ab). Neurons were then treated for $24 \mathrm{~h}$ with vehicle or $1 \mu \mathrm{MA} \beta_{1-42}$ oligomers. Cell viability was monitored using the MTT assay. Data are means \pm SEM of three independent experiments with four determinations each, normalized to the effect of vehicle, designated as $100 \%$. No significant differences were found between untreated cells and cells incubated with CM from encapsulated control cells, as well as between cells incubated with $A \beta$ oligomers in the absence or presence of $C M$ from control encapsulated cells (data not shown). $B, A \beta$ oligomer-induced neurodegeneration is associated with neuronal cytoskeleton disruption (Sponne et al., 2003; Fifre et al., 2006). Seven DIV neurons were exposed for $12 \mathrm{~h}$ to $1 \mu \mathrm{m} \mathrm{A} \beta_{1-42}$ oligomers in the presence or absence of CM from encapsulated CNTF cells containing $1 \mathrm{~nm}$ CNTF. Cultures were fixed and immunostained for MAP2 to visualize dendrites. In the presence of $\mathrm{CM}$ alone, dystrophic changes including beading and fragmentation were rare. In contrast, $A \beta$ oligomers induced a severe disruption of the cytoskeleton network that was markedly reduced in the presence of secreted CNTF. The presence of CM from encapsulated control cells did not prevent $A \beta$ oligomer-induced cytoskeleton disruption. The A $\beta$-induced microtubule perturbations were quantified as indicated in Materials and Methods and also as described previously (Sponne et al., 2003 ; Fifre et al., 2006). C, Apoptotic nuclei were visualized using DAPI staining and quantified as described in Materials and Methods [16 fields from 4 wells (>1000 cells per group) were examined for quantification]. A $\beta$ oligomers caused a significant increase in apoptotic nuclei that was almost completely inhibited in the presence of secreted CNTF but not by the CM of encapsulated control cells. $D$, Cells were also exposed for $6 \mathrm{~h}$ to $1 \mu \mathrm{M} \mathrm{A} \beta_{1-42}$ oligomers, and caspase activation was monitored by measuring the proteolytic cleavage of caspase-related substrates. Data are means \pm SEM of three independent experiments with four determinations each $(p<0.05)$. $\boldsymbol{E}$, Representative immunoblots showing the inhibitory effects of CM from encapsulated CNTF cells containing $1 \mathrm{~nm}$ CNTF on A $\beta$ oligomer-induced caspase and calpain activation as well as decrease in MAP2 levels.

tikine, Human CNTF; R \& D Systems Europe). The amount of CNTF (picograms) secreted per bead in $24 \mathrm{~h}$ was calculated.

\section{Statistical analysis}

STATVIEW computer software was used for the statistical analysis. Data were obtained from three to five separate experiments with six determinations each. Differences between control and treated groups were analyzed using Student's $t$ test $\left.{ }^{* *} p<0.05,{ }^{* * *} p<0.001\right)$. Multiple pairwise comparisons among the groups of data were performed using ANOVA, followed by a Scheffé's post hoc test $(p<0.05$ indicates significant differences between groups). For behavioral analysis, statistical comparisons were made by the Student's $t$ test, and one-way ANOVA was performed and followed by Fisher's post hoc test. Values of $p<0.05$ indicate significant differences between experimental groups. All reported values represent the mean \pm SEM.

\section{Results}

\section{C2C12 cell encapsulation and CNTF secretion}

C2C12 myoblast cells continuously expressing hCNTF with or without a reporter gene (eGFP) were encapsulated in ultrapure alginate beads with high $\mathrm{G}$ content. Cell capsules (containing 500-1000 C2C12 cells) were intact and alive for $>8$ months in vitro as identified by fluorescence reporter gene expression (Fig. $1 A)$. CNTF secretion from the capsules was measured at different time points in culture. The concentration achieved was estimated to $1-2$ pg per $24 \mathrm{~h}$ per alginate bead. After an initial stabilization period (5-10 d), CNTF production from the encapsulated cells was constant throughout the time period (up to 8 months in vitro) (Fig. $1 B, C)$.

\section{CNTF rescues neurons from $A \boldsymbol{\beta}$ oligomer-induced} degeneration in vitro

We have demonstrated previously that neuronal cell death induced by soluble $\mathrm{A} \beta$ oligomers proceeds through an apoptotic pathway involving an early cytoskeleton perturbation triggered by calpain and caspase activation (Pillot et al., 1999; Sponne et al., 2003; Fifre et al., 2006). The incubation of primary mouse neurons with $1 \mu \mathrm{M} \mathrm{A} \beta_{1-42}$ oligomers for $24 \mathrm{~h}$ resulted in a $38.4 \%$ $(p<0.001$ compared with vehicle-treated cells) decrease in cell viability (Fig. $2 A$ ). A $2 \mathrm{~h}$ preincubation with CNTF dose dependently protected neurons from $\mathrm{A} \beta$ oligomer-induced cell death. Complete protection by $\mathrm{CNTF}$ ( $98.2 \pm 2.6 \%$ cell viability relative to vehicle control cells) was observed with a dose of $10 \mathrm{nM}$. ANOVA indicated a significant protective effect of CNTF at all concentrations tested (0.1-10 nM) (Fig. 2A). Furthermore, the presence of a CNTF receptor antibody almost completely blocked the CNTF protective effects $(p<0.05$ compared with cells treated with vehicle in the presence of CNTF receptor antibody) (Fig. 2A). These CNTF-specific neuroprotective effects (Fig. $2 B$ ) (see Fig. 4A) were accompanied by the inhibition of apoptotic pathways (Fig. 2C), including caspase and calpain inhibition (Fig. $2 D, E)$. 
Stabilization of synaptic protein expression and activation of the PI3K and JAK/STAT signaling pathways by CNTF

Synaptic dysfunction is increasingly considered as an early event in AD pathogenesis (Selkoe, 2002). Indeed, it has been demonstrated recently that $\mathrm{A} \beta$ oligomers impair synaptic function through the alteration of both the level and localization of synapse-associated proteins (Almeida et al., 2005; Kelly et al., 2005). To address the mechanism involved in CNTFinduced neuroprotection against $\mathrm{A} \beta$, we investigated the expression of synaptic proteins and signaling pathways activated by CNTF. The treatment of mouse neurons with $\mathrm{A} \beta_{1-42}$ oligomers ( $1 \mu \mathrm{M}$ for $3 \mathrm{~h}$ ) resulted in a dramatic decrease in the levels of the glutamate receptor subunit GluR1 level and of PSD95 in synaptic membranes (Fig. 3A). We show that $1 \mathrm{~nm}$ CNTF prevented $\mathrm{A} \beta$ oligomer-induced decrease in synaptic proteins, whereas anti-CNTF receptor antibodies abolished the protective effects of CNTF on synaptic markers (Fig. 3A). CNTF has been demonstrated to activate multiple survival signal transduction pathways that require phosphorylation (Garza et al., 2008) and that are impaired by soluble $\mathrm{A} \beta$ oligomers (Florent et al., 2006). To determine the signaling pathways that can be activated and improved by $1 \mathrm{nM}$ CNTF in mouse neurons exposed to $A \beta$ oligomers, phosphorylation of Akt $\left(\operatorname{Ser}^{473}\right)$, CREB $\left(\right.$ Ser $\left.^{133}\right)$ and STAT3 $\left(\right.$ Tyr $\left.^{705}\right)$ was evaluated by immunoblot. Neurons exposed for $3 \mathrm{~h}$ to $1 \mu \mathrm{M} \mathrm{A} \beta_{1-42}$ oligomers in the presence of $\mathrm{CM}$ from encapsulated control cells exhibited a dramatic decrease in the level of phosphorylated forms of Akt, STAT3, and CREB, strongly suggesting that the corresponding survival pathways are impaired by $\mathrm{A} \beta$ oligomers (Fig. $3 A$ ). In contrast, the presence of $\mathrm{CM}$ from encapsulated $\mathrm{C} 2 \mathrm{C} 12-\mathrm{CNTF}$ cells markedly inhibited the decrease in phosphorylation of all kinases tested (Fig. 3A) (for immunoblot quantification, see supplemental Fig. 1, available at www.jneurosci.org as supplemental material). Interestingly, CNTF-directed antibodies prevented the protective effects of CNTF on the survival signaling pathways (Fig. 3A) (supplemental Fig. 1, available at www.jneurosci.org as supplemental material). These data demonstrate that the PI3K/Akt and the JAK/ STAT3 signaling pathways are recruited by CNTF in mouse neurons. Moreover, it is worth noting that activation of the CREB pathway was also preserved by exogenous CNTF in mouse neurons, strongly suggesting that CNTF maintains an efficient survival signaling, thereby preventing neuronal cell death. To further confirm that the PI3K/Akt signaling pathway mediates the action of CNTF on neuronal survival, cells were exposed to the widely used PI3K-specific inhibitor LY294002 [2-(4-morpholinyl)-8-phenyl-1(4H)-benzopyran-4-one], followed by $\mathrm{A} \beta_{1-42}$ oligomer treatment. The pretreatment with LY294002 significantly reduced the neuroprotective effects of CNTF (Fig. 3B). Sim-

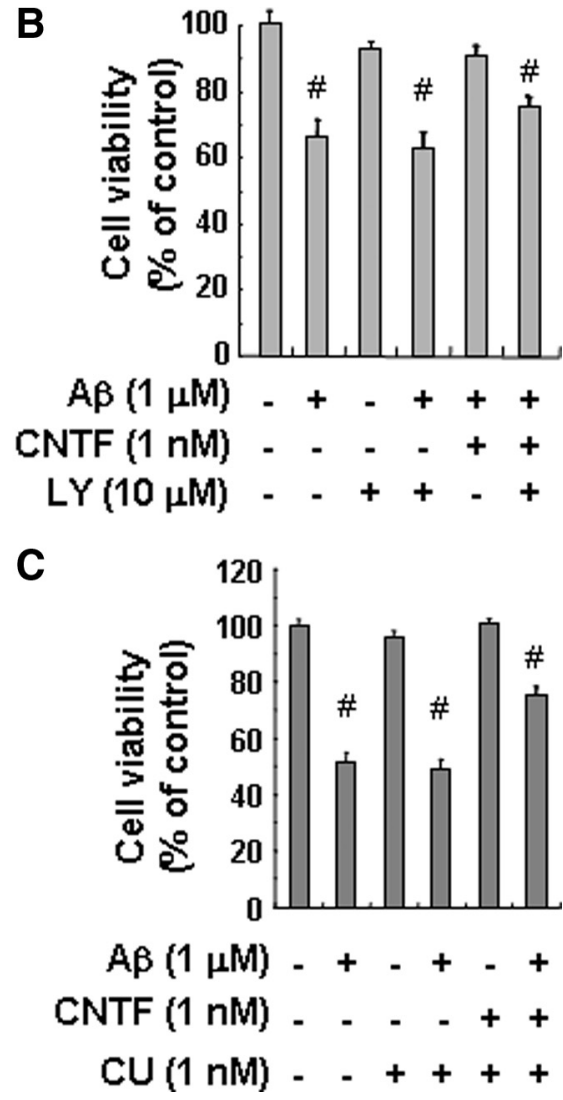

Figure 3. Molecular mechanisms of CNTF-induced neuroprotection. $A$, Representative immunoblot of protein extracts isolated from neurons at 7 DIV exposed for $3 \mathrm{~h}$ to $1 \mu \mathrm{MA} \beta_{1-42}$ oligomers in the presence of CNTF CM or control CM. All protein preparations derived from separate experiments; three independent immunoblot analyses were conducted. Quantification is shown in supplemental Figure 1 (available at www.jneurosci.org as supplemental materia). CNTRR Ab, CNTF receptor antibodies. Alternaeach, normalized to the effect of vehicle, designated as $100 \%$. "Values of $p<0.05$ indicate significant differences between treatments in the absence or presence of $A \beta$ oligomers.

ilarly, the presence of the STAT3 inhibitor cucurbitacin I also reduced the CNTF effects (Fig. 3C).

Altogether, our in vitro data are consistent with a previously unknown neuroprotective role of CNTF against $\mathrm{A} \beta$ oligomer-induced synaptic and neuronal degeneration, an effect that is mediated at least in part through the PI3K and JAK/STAT signaling pathways.

CNTF specifically prevents neuronal death induced by $\mathrm{A} \beta$ oligomer but not by fibrillar form of $\mathrm{A} \boldsymbol{\beta}$

We next investigated the effects of CNTF on the neurotoxicity induced by fibrillar $\mathrm{A} \beta$ prepared as described previously (Sponne et al., 2004; Youssef et al., 2008). Under similar experimental conditions, CNTF failed to prevent neuronal death induced by fibrillar $\mathrm{A} \beta_{1-42}$ (Fig. $4 \mathrm{~B}$ ). This corroborates our previous data strongly suggesting that the cellular targets and the molecular mechanisms involved in neuronal death induced by A $\beta$ strongly depends on peptide conformation (Pillot et al., 1999; Sponne et al., 2003, 2004; Kriem et al., 2005). Although pretreatment or concomitant application of CNTF with $\mathrm{A} \beta_{1-42}$ oligomers results in strong neuroprotection, the addition of CNTF after $\mathrm{A} \beta$ treatment (15 min up to $1 \mathrm{~h}$ ) elicited no significant effects (Fig. 4C). Thus, CNTF neuroprotective effects most likely require direct CNTF-induced cell signaling and activated pathways. 

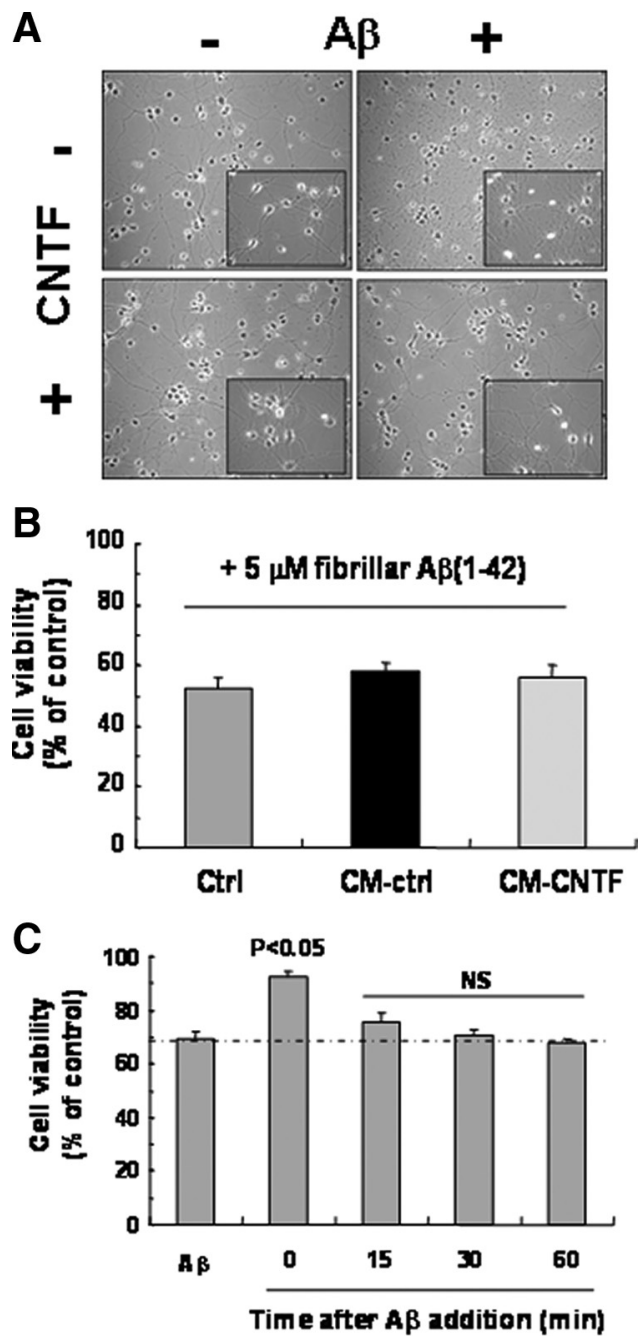

Figure 4. Protective effects of CNTF on $A \beta$ oligomer (but not $A \beta$ fibril)-induced neurodegeneration. $A$, Representative micrographs on mouse neurons treated for $12 \mathrm{~h}$ with $1 \mu \mathrm{M}$ $A \beta_{1-42}$ oligomers in the absence or presence of conditioned medium from encapsulated C 2 C12 ${ }^{\text {CTRL }}$ or $\mathrm{C} 2 \mathrm{C}_{12}{ }^{\text {CNTF }}$ cells containing $10 \mathrm{~nm}$ CNTF. B, Mouse neurons were incubated for $24 \mathrm{~h}$ with $5 \mu \mathrm{m}$ fibrillar $A \beta_{1-42}$ in the presence or absence of $10 \mathrm{~nm}$ CNTF, and cell viability was assessed using the MTT assay. No significant differences were found between the different groups. C, Cells were treated for $24 \mathrm{~h}$ with $1 \mu \mathrm{m} \mathrm{A} \beta_{1-42}$ oligomers in the absence or presence of $1 \mathrm{~nm}$ CNTF added at the same time or up to 60 min after the addition of $A \beta$ oligomers. Cell survival was monitored by the MTT assay. Data are means \pm SEM of three independent experiments with four determinations each, normalized to the effect of vehicle, designated as $100 \%$. Values of $p<0.05$ indicate significant differences.

CNTF rescues mice from $\mathrm{A} \boldsymbol{\beta}$ oligomer-induced cognitive and synaptic impairment

We next investigated whether continuous delivery of CNTF in vivo could prevent $\mathrm{AD}$-like symptoms resulting from acute exposure of mouse brain to soluble $\mathrm{A} \beta$ oligomers in a recently developed mouse model for mild cognitive impairment (Youssef et al., 2008).

Male C57BL/6 mice ( $n=12$ per group) were intracerebroventricularly implanted at the age of 3 months with one alginate bead containing 500-1000 C2C12-CNTF or control C2C12 cells, followed 3 weeks later by an intracerebroventricular injection of $\mathrm{A} \beta$ oligomers or vehicle. The cognitive performances of mice were monitored by $\mathrm{Y}$-maze and water-maze behavioral tests as described previously (Youssef et al., 2008). A $\beta_{1-42}$ oligomerinjected mice implanted with a $\mathrm{C} 2 \mathrm{C} 12-\mathrm{CNTF}$ capsule exhibited significantly better cognitive capacities compared with animals grafted with a control capsule (Fig. 5). Indeed, CNTF delivery significantly improved spatial working memory (Fig. $5 A$ ), learning capability (Fig. $5 B, C$ ), and long-term memory (Fig. $5 D-F$ ) in $\mathrm{A} \beta$ oligomer-injected mice. Mice implanted with an alginate bead containing C2C12-CNTF cells were indistinguishable from animals engrafted with an alginate bead containing C2C12 control cells and injected with vehicle, indicating that CNTF alone does not interfere with cognitive performances. It is important to note that we were able to monitor in the animal an intact alginate bead containing living CNTF and eGFP-expressing cells 8 weeks after bead implantation (Fig. $5 G$ ).

The effects of CNTF delivery on behavioral performances could not be attributed to generalized exploratory, locomotor, or motivational effects (data not shown). Moreover, the water-maze task performed on days 3 and 4 after injection of $A \beta$ with a visible platform failed to reveal any difference in visual and motor abilities between all groups (data not shown). Similar behavioral improvement was also observed when CNTF-encapsulated cells were implanted above the CA1 subfield of hippocampus (data not shown). Moreover, CNTF-mediated improvement of cognitive functions could not be attributed to nonspecific interactions of $A \beta$ oligomers with the alginate bead because implantation of empty capsules under similar experimental conditions had no impact on $\mathrm{A} \beta$ oligomer-induced cognitive impairment (supplemental Fig. 2, available at www.jneurosci.org as supplemental material). Interestingly, animals implanted with empty capsules or with capsules containing control $\mathrm{C} 2 \mathrm{C} 12$ cells exhibited similar behavioral performances after intracerebroventricular injection of vehicle or $\mathrm{A} \beta$ oligomers (Fig. 5) (supplemental Fig. 2, available at www.jneurosci.org as supplemental material).

Because alginate capsule containing 500-1000 C2C12-CNTF cells secreted low amounts of CNTF (Fig. 1C), we were unable to detect CNTF by ELISA in the CSF or brain tissues of implanted animals (data not shown). To confirm that CNTF is the responsible agent, we directly infused CNTF 1 week before intracerebroventricular injection of $\mathrm{A} \beta$ oligomers. Whereas the intracerebroventricular injection of 10 pmol of CNTF had no effect on $\mathrm{A} \beta$ oligomer-induced cognitive deficits (data not shown), the intracerebroventricular injection of a higher dose of CNTF (1 nmol of CNTF) clearly protected mice from $\mathrm{A} \beta$ induced impairment of short-term memory [76 \pm 3.8 and $58 \pm$ $4.1 \%(p<0.05)$ alternation for mice intracerebroventricularly injected with $\mathrm{A} \beta$ oligomers in the presence and absence of CNTF, respectively] and long-term memory (supplemental Fig. 3, available at www.jneurosci.org as supplemental material). Together, our data strongly support the notion that the rescuing activity of implanted alginate beads might be attributed to released CNTF.

In summary, we clearly show that short- and long-term memory deficits induced by a single injection of $A \beta$ oligomers can be fully reverted during local CNTF delivery.

\section{CNTF prevents changes in hippocampal synaptic protein expression in vivo}

Synaptic failure resulting from the interaction of $\mathrm{A} \beta$ oligomers with synaptic terminals presumably represents a morphological correlate of the progressive impairment of cognitive function and is considered as an early event in AD pathogenesis (Yankner and Lu, 2009). Here, we show that CNTF-mediated improvement of cognitive functions was accompanied by the preservation of synaptic protein levels in the hippocampus of engrafted animals. After $\mathrm{A} \beta$ oligomer injection, synaptosome-associated protein levels in the hippocampus were significantly decreased. Both presynaptic and postsynaptic proteins were affected, including 
A

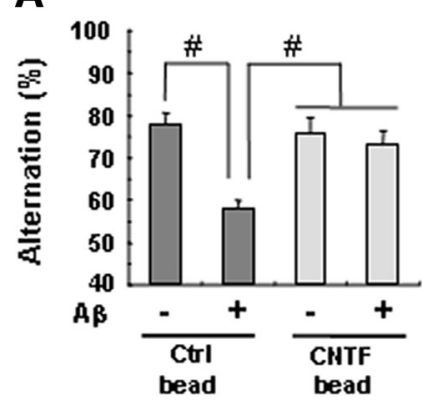

D

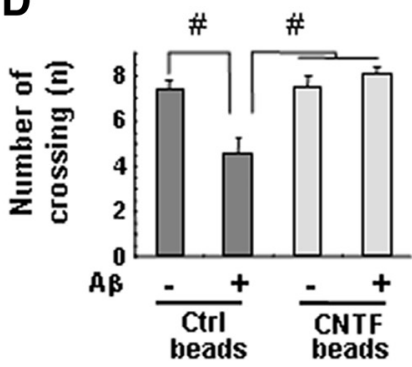

G

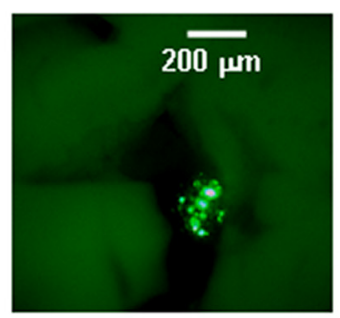

B

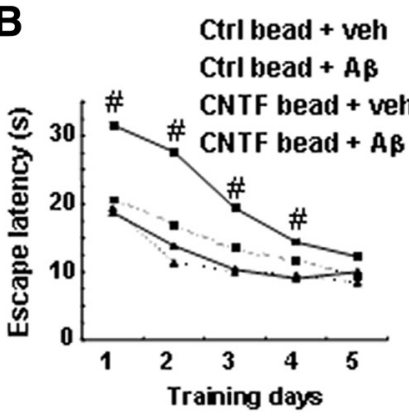

E

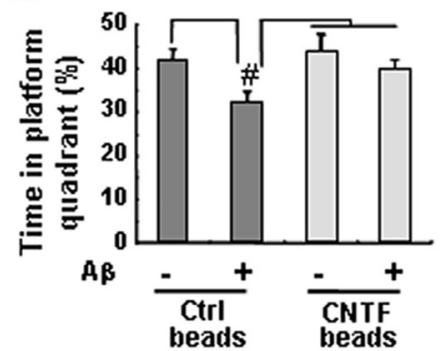

C

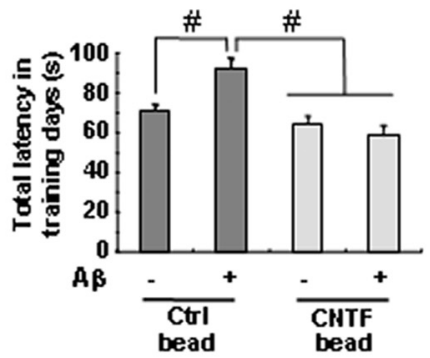

F

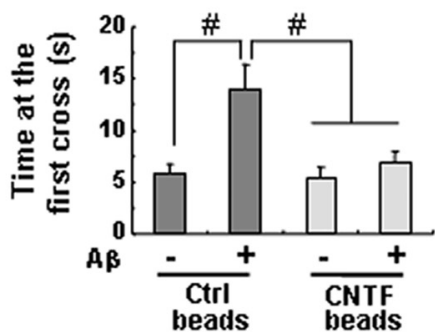

H

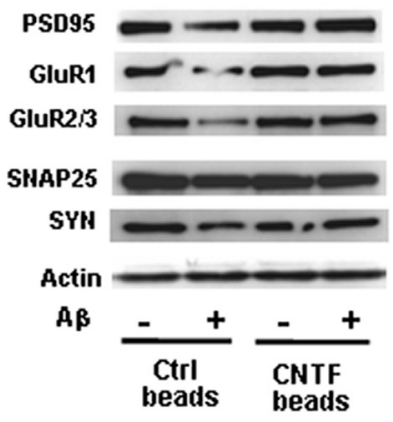

1

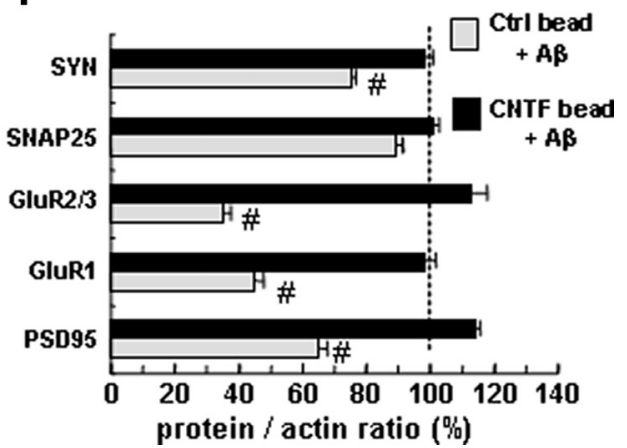

Figure 5. Continuous CNTF secretion prevents cognitive and synaptic impairments in $A \beta$ oligomer-infused mice. $A$, The $Y$-maze tests were performed $4 \mathrm{~d}$ after $A \beta$ oligomer or vehicle injection, and spontaneous alternation behavior was measured during a 5 min session as previously described (Youssef et al., 2008). The number of arm entries did not differ among the different groups of mice (data not shown). The water-maze tests were performed as described previously (Youssef et al., 2008). The training trials were performed on days $7-11$ after $A \beta$ or vehicle injection. The latency showed the mean of a block of four trials per day. Escape latency $(\boldsymbol{B})$ and cumulated total latency in training days $(\boldsymbol{C})$ were recorded. The probe trial was performed on day 14 after $A \beta$ or vehicle injection. The number of crossings over the platform site $(\boldsymbol{D})$, the percentage of time spent in the platform quadrant $(\boldsymbol{E})$, as well as the time required for the first crossing over the platform site $(\boldsymbol{F})$ were recorded. All data are presented as means \pm SEM $(n=11)$. All mice showed normal swimming performance and constant increase in body weight. It is worth noting that similar protective effects of CNTF have been observed when alginate beads were implanted in the subhippocampal region of mouse brain (data not shown). G, Survival of encapsulated eGFP-CNTF-C2C12 cells was verified at 8 weeks after implantation. Microscopic observation of freshly dissected brain showed the presence of an intact capsule containing living cells. $\boldsymbol{H}$, After behavioral tests, hippocampal synaptosomes were prepared as described in Materials and Methods and analyzed by immunoblot. Representative immunoblots of synaptic hippocampal proteins of mice implanted with alginate beads containing control or CNTF-C2C12 cells and intracerebroventricularly injected with vehicle or A $\beta$ oligomers. I, Densitometric analysis of immunoblots was performed with normalization to actin. Data are presented as means \pm SEM of three separate immunoblots ( $n=6$ mice per group). ${ }^{\#} p<0.05$ indicate significant differences between animals injected with $A \beta$ in the presence of control or CNTF beads.

PSD95, GluR1, GluR2/3, SNAP25, and synaptophysin (Fig. 5H). In contrast, CNTF delivery completely prevented the $\mathrm{A} \beta$ oligomer-induced decrease in synaptic proteins. This observation was confirmed by immunoblot quantification (Fig. 5I). Interestingly, the levels of all synaptic proteins tested were indistinguishable in animals engrafted with $\mathrm{C} 2 \mathrm{C} 12-\mathrm{CNTF}$ cells and injected with vehicle or $\mathrm{A} \beta$ oligomers compared with mice receiving $\mathrm{C} 2 \mathrm{C} 12$ control cells, followed by vehicle injection (Fig. $5 H, I)$. Together, these data clearly demonstrate that continuous delivery of CNTF directly protects hippocampal synapses by maintaining stable protein levels.

Engrafted CNTF-producing cells inhibit cognitive impairment in mutant APP-expressing Tg2576 mice

We next examined whether CNTF delivery influences synaptic and neuronal degeneration in a transgenic mouse model re- flecting the progressive nature of AD pathology. The Tg2576 transgenic mice express human amyloid precursor transgene (APP695) bearing missense mutations that cause AD in humans (HuAPP695.K670N-M671L). Four alginate capsules containing C2C12-CNTF ( $n=15, \mathrm{Tg}^{\text {CNTF }}$ mice) or C2C12 control cells ( $n=16, \mathrm{Tg}^{\mathrm{CTRL}}$ mice) were bilaterally intracerebroventricularly injected at the age of 5 months. Age-matched wild-type (WT CTRL and WT ${ }^{\mathrm{CNTF}}$ mice, $n=10$ per group) littermates underwent similar surgery. Cognitive performances were monitored as a function of time. Short-term memory was evaluated monthly in the Y maze. As reported previously (Westerman et al., 2002; Young et al., 2009), $\mathrm{Tg}^{\mathrm{CTRL}}$ mice showed progressive impairment of working memory beginning at 6-8 months (Fig. 6A). In this frontal cortex-dependent task, $\mathrm{Tg}^{\mathrm{CNTF}}$ mice demonstrated significant amelioration of short-term memory deficits compared 

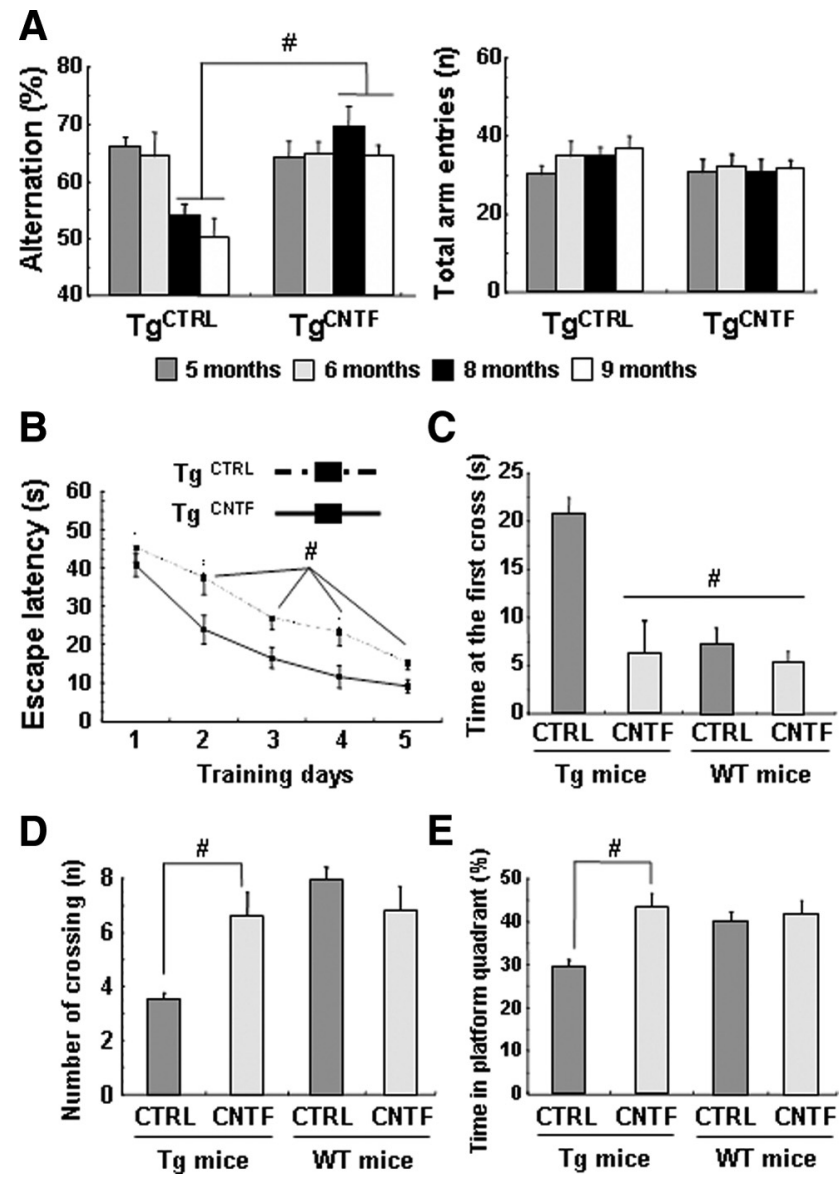

Figure 6. CNTF secretion prevents impairment of cognitive functions in Tg2576 AD mouse model. At 5 months of age, $\operatorname{Tg} 2576$ mice ( $\mathrm{Tg} ; n=15-16$ per group) or age-matched littermate mice (WT; $n=10$ per group) were intracerebroventricularly implanted with four alginate beads containing 500-1000 control C2C12 (Tg ${ }^{\text {CTRL }}$ or WT ${ }^{\text {CRRL }}$ ) or CNTF-C2C12 (Tg ${ }^{\text {CNTF }}$ or WT ${ }^{\text {CNTF }}$ ) cells as described in Materials and Methods. Short-term memory was monitored monthly using the $Y$-maze test as indicated $(\boldsymbol{A})$. At 9 months of age, learning capacities and long-term memory were measured using the water-maze test. The training trials were performed, and the mean latency of a block of four trials per day was calculated $(\boldsymbol{B})$. During the probe trials, the time required for the first cross over the platform site $(\boldsymbol{C})$, the number of crossings over platform site $(\boldsymbol{D})$, as well as the percentage of time spent in the platform quadrant $(\boldsymbol{E})$ were recorded. All data are presented as means \pm SEM ( ${ }^{\#} p<0.05$ indicates significant differences between $\mathrm{Tg}^{\text {(TRL }}$ and $\mathrm{Tg}^{\text {(NTF }}$ mice). $\mathrm{Tg}^{\text {CNTF }}$ mice and WT ${ }^{\text {CTR }}$ or WT ${ }^{\text {CNTF }}$ were not statistically different. WT ${ }^{\text {CTRL }}$ and WT ${ }^{\text {CNTF }}$ were not statistically different and exhibited similar cognitive performances compared with untreated wild-type mice (data not shown). All mice showed normal swimming performance and had no difference in body weight gain during the entire experimental period.

with $\mathrm{Tg}^{\mathrm{CTRL}}$ mice. The performances of $\mathrm{WT}^{\mathrm{CNTF}}$ mice were not different from that of Tg ${ }^{\text {CNTF }}$ mice, nor did the number of arm entries change significantly in the different experimental groups (data not shown). This indicated that preservation of alternation behavior in Tg ${ }^{\mathrm{CNTF}}$ mice was not attributable to generalized exploratory, locomotor, or motivational effects (Sarter et al., 1988). Spatial learning and memory were then tested in the water maze on 9-month-old transgenic mice (Fig. 6). Over five successive daily blocks of trials, significant amelioration of spatial memory deficits were observed in $\mathrm{Tg}^{\mathrm{CNTF}}$ mice compared with Tg ${ }^{\mathrm{CTRL}}$ mice (Fig. 6B). Again, the performances of implanted littermates were not different from that of $\mathrm{Tg}^{\mathrm{CNTF}}$ mice (data not shown). Furthermore, CNTF delivery completely preserved long-term memory on all three measures of water-maze performances. Indeed, latency on test trials (Fig. 6C), platform crossings (Fig. 6D), and time spent in the target quadrant (Fig. 6E) were not significantly different in $\mathrm{Tg}^{\mathrm{CNTF}}$ and $\mathrm{WT}^{\mathrm{CNTF}}$ mice.
Finally, Tg ${ }^{\text {CNTF }}$ mice showed marked improvement of search strategy, with greater swimming around the platform location (data not shown). Weight loss, a possible side effect of growth factor delivery in the CNS, did not occur (2.3 and 2.1\% gain in $\mathrm{Tg}^{\mathrm{CNTF}}$ and $\mathrm{Tg}^{\mathrm{CTRL}}$, respectively). The CNTF-dependent protection of cognitive functions in $\mathrm{Tg}^{\mathrm{CNTF}}$ mice could not be attributed to nonspecific effects on cognition. Indeed, CNTF delivery in the brain of nontransgenic animals had no effect on the performance of littermate mice at any age (Fig. $6 D, E$ ). Thus, $\mathrm{CNTF}$ was able to halt cognitive deterioration in an AD mouse model undergoing a progressive deterioration of behavioral performances.

\section{Molecular mechanisms involved in therapeutic effects of CNTF in Tg2576 mice}

Synaptic pruning is a feature of both human $\mathrm{AD}$ and of $\mathrm{AD}$-like insults in Tg2576 mice. This presumably reflects a chronic exposure of synaptic terminals to soluble $\mathrm{A} \beta$ oligomers representing a morphological alteration that correlates with cognitive impairment in these mice. CNTF-induced functional improvement of cognitive functions in transgenic mice was associated with a significant increase in hippocampal presynaptic and postsynaptic proteins, whereas no change was observed in cortical synaptosomes (Fig. 7A-C). Indeed, CNTF delivery induced a significant recovery of AMPA receptor (i.e., GluR1 and GluR2/3) and their associated proteins PSD95 and stargazin, as well as synaptophysin, a marker of synaptic density (Fig. $7 A, B$ ). In addition, the levels of synaptic proteins were positively correlated with the performances of mice in the water-maze probe trials as illustrated in Figure $7 D$ for GluR1, thus allowing discrimination between $\mathrm{Tg}^{\mathrm{CNTF}}$ and $\mathrm{Tg}^{\mathrm{CTRL}}$ mice.

To characterize the signaling pathways involved in CNTFinduced neuroprotection in $\mathrm{Tg}{ }^{\mathrm{CNTF}}$ mice, we analyzed by immunoblot the hippocampal levels of phosphorylated forms of STAT3 and JAK-1 proteins. In Tg ${ }^{\text {CNTF }}$ mice, the levels of P-JAK-1 and P-STAT3 were significantly higher, thereby maintaining the cell signaling related to CNTF receptor $\alpha / \mathrm{CNTF}$ pathways (Fig. $7 E)$. There were no changes in the total levels of JAK-1 and STAT-3, whereas a significant increase (45 and 52\%) in JAK-1 and STAT-3 phosphorylation (respectively) was detected (Fig. $7 E$ ) in the hippocampus of $\mathrm{Tg}^{\mathrm{CNTF}}$ mice compared with $\mathrm{Tg}$ CTRL mice $(p<0.05 ; n=6)$. Notably, the levels of phosphorylated forms of these two proteins were also positively correlated with the performances of mice in the water-maze probe trials (data not shown). CNTF treatment also significantly preserved Akt phosphorylation levels, indicating protection of the cell signaling that controls functional state and survival of neurons in $\mathrm{Tg}^{\mathrm{CNTF}}$ mice (Fig. 7E). Finally, it is important to note that CNTF delivery affected neither APP levels in hippocampal and cortical synaptosomes (Fig. $7 A-C$ ) nor soluble and fibrillar $\mathrm{A} \beta$ peptide levels (Fig. $7 F$ ), indicating that a reduction of $\mathrm{A} \beta$ levels is not necessary to induce a functional recovery in this $\mathrm{AD}$ mouse model.

In summary, we show that the therapeutic effects of CNTF on cognitive performances in Tg2576 mice involves the preservation of synaptic proteins, activates both JAK/STAT and Akt survival pathways in the hippocampus, and are likely to occur independently of a direct modulation of amyloid production in Tg CNTF mice.

\section{Discussion}

Modulation of the amyloid pathology represents a key therapeutic target to delay $\mathrm{AD}$. In addition to strategies designed to decrease A $\beta$ levels (Klafki et al., 2006), successful AD therapeutics 
will likely require the concomitant application of neuroprotective agents to stop ongoing synaptic and cognitive deterioration (Longo and Massa, 2004). It is clear that $A \beta$ oligomers disrupt synaptic functions, leading to altered cognitive performances (Rowan et al., 2007; Youssef et al., 2008). Therefore, protection from the synaptotoxicity of $\mathrm{A} \beta$ oligomers is necessary to prevent $\mathrm{AD}$-associated neurodegeneration. The broad neuroprotective activity of CNTF toward different cytotoxic insults (Hagg, 2009) prompted us to study the potency of CNTF in preventing synaptic degeneration induced by $\mathrm{A} \beta$ oligomers in $\mathrm{AD}$ mouse models.

Here, we provide strong evidence that local and long-term delivery of low-dose CNTF prevents $A \beta$ oligomer-induced synaptic impairment and subsequent cognitive deficits in $\mathrm{AD}$ models submitted to acute or chronic exposure to $\mathrm{A} \beta$ oligomers. This approach was based on the observation that CNTF protects neurons from $\mathrm{A} \beta$ oligomer-induced degeneration in vitro. Indeed, CNTF prevents $\mathrm{A} \beta$ oligomer-induced decrease of synaptic proteins, impairment of cell signaling, and cytoskeleton breakdown, as well as the subsequent activation of apoptotic events. Accordingly, CNTF prevents cognitive alterations in mice challenged with a single injection of $\mathrm{A} \beta$ oligomers, a mouse model of early cognitive impairment associated with AD (Youssef et al., 2008). The beneficial effect was observed with continuous low-dose delivery of CNTF, as well as with a high dose $(1 \mathrm{nmol})$ of CNTF injection. We were unable to detect CNTF in the CSF or in brain extracts at neither early nor late time points after capsule implantation. This is most likely explained by the fact that a single capsule was implanted and the concentration of released CNTF (1-2 pg/bead per day) is below the detection limit of the ELISA kit $(\sim 20 \mathrm{pg} / \mathrm{ml})$. However, we provide evidence that implanted capsules contain living cells even 8 weeks after implantation (Fig. 5G). Because NTFs exert their effects at low concentrations (picomolar range), the inability to detect CNTF does not mean that it is not released and active in this concentration range. In this respect, it should be noted that the low CNTF concentration achieved may be considered an advantage because it circumvents potential major side effects of increased CNTF levels (Kishima et al., 2004; Yasuhara et al., 2005).

Remarkably, this was associated with stabilization of synapticassociated proteins in the hippocampus of $\mathrm{A} \beta$ oligomer-injected mice. We further show that CNTF delivery improves AD-like phenotype in an APP transgenic mouse used as a robust and clinically highly relevant model of AD (Mucke et al., 2000). Finally, we provide evidence that in vitro and in vivo CNTF-induced synaptic stabilization and neuronal survival are mediated through the JAK/STAT and PI3K signaling pathways. We could not detect hCNTF (by ELISA) in both the CSF and brain tissues of implanted mice (data not shown), which most likely reflects its low level of secretion and/or its rapid diffusion into the parenchyma, as described previously for brain glial
B

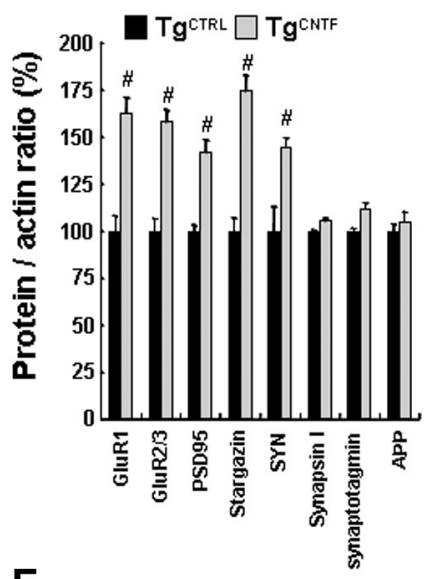

E

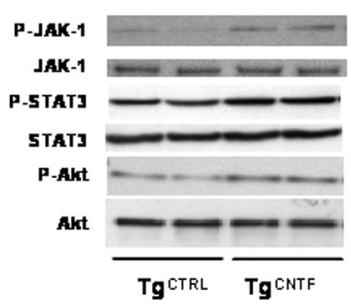

C

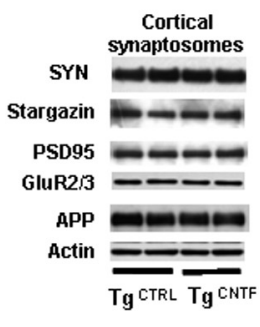

$\mathbf{F}$
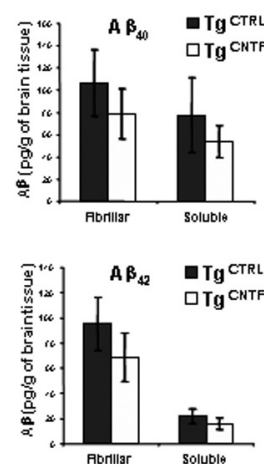

Figure 7. CNTF delivery prevents synaptic impairment and preserves cell signaling independently of amyloid in Tg2576 AD mouse model. After the behavioral analysis was completed, mice were killed, and synaptosomes from different brain regions were normalization to actin. Data are presented as means \pm SEM of three separate immunoblots ( $n=6$ mice per group). $C$, Represen-

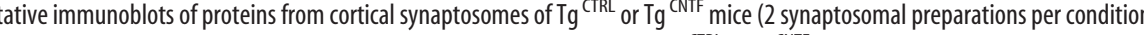

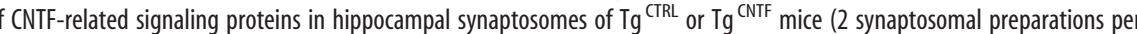
condition are shown). $\boldsymbol{F}$, Brain levels of $A \beta_{40}$ and $A \beta_{42}$ peptides (fibrillar and soluble) were measured by ELISA tests in 9-monthold $\mathrm{Tg}^{\text {CTRL }}$ or Tg ${ }^{\text {CNTF }}$ mice ( $n=6$ mice per group). Data are presented as the mean \pm SEM and were not significantly different between $\mathrm{Tg}^{\mathrm{CTRL}}$ and $\mathrm{Tg}^{\mathrm{CNTF}}$ mice. ${ }^{\#} p<0.05$.

cell line-derived neurotrophic factor delivery using encapsulated cells (Kishima et al., 2004). Nevertheless, we could demonstrate the presence of intact capsules containing living eGFP-expressing cells even at 8 months after alginate bead implantation in Tg2576 mice (data not shown). We show here that, despite the low doses of trophic factor delivered, CNTF-producing encapsulated cells implanted in two $\mathrm{AD}$ mouse model induced a recovery of cognitive performances. This represents a promising therapeutic approach for $\mathrm{AD}$, providing a major alternative and/or complementary strategy to amyloid-modifying therapeutics.

Tg2576 mice, expressing the Swedish mutation of hAPP, are the most thoroughly characterized AD mouse model and can be considered as "diseased mice" long before amyloid pathology (i.e., appearance of amyloid plaques) occurred (Hsiao et al., 1996; Westerman et al., 2002). Whereas A $\beta$ plaques appear after 8-9 months (Kawarabayashi et al., 2001), these mice exhibit progressive cognitive decline starting at the age of 4 months, probably reflecting synaptic pruning attributable to chronic synaptotoxic effects of A $\beta$ oligomers (Kawarabayashi et al., 2004; Young et al., 2009). Accordingly, 5- to 8-month-old Tg2576 mice are often used as a model of mild cognitive impairment. When treatment was initiated at the end of the prodromal phase (i.e., at the age of 5 months), CNTF stabilized molecular, synaptic, and behavioral parameters of Tg2576 mice. Interestingly, CNTF treatment affected neither the quantity of synaptosomal APP nor the amount of $\mathrm{A} \beta$ peptide produced in the brain, indicating that CNTF- 
induced protection in this model occurs independently of amyloid pathology.

As reported previously with membrane cholesterol (Sponne et al., 2004) and docosahexaenoic acid status (Florent et al., 2006), $\mathrm{CNTF}$ had no protective effects on fibrillar $\mathrm{A} \beta$-induced neuronal death. These observations strongly suggest that the cellular response depends on $\mathrm{A} \beta$ peptide structure. These data have been corroborated by several studies underlying differential effects of soluble oligomeric and fibrillar $\mathrm{A} \beta$ structures on cell activation and/or degeneration (Dahlgren et al., 2002; Kim et al., 2003; White et al., 2005). Because fibrillar $A \beta$ also impaired the JAK-1/ STAT3 and PI3K signaling pathways (data not shown), it is likely that fibrillar $A \beta$ induced neuronal degeneration and death through major pathways that are not targeted by CNTF. Indeed, whereas neuronal degeneration induced by $\mathrm{A} \beta$ oligomers involves a caspase 8 -independent pathway, cell death triggered by fibrillar $A \beta$ clearly involves the activation of caspase 8 (Pillot et al., 1999; Sponne et al., 2003; Fifre et al., 2006). Together, these data suggest that the design of AD therapeutics must take into account the structure of the $\mathrm{A} \beta$ peptide that is to be targeted.

Here, we provide evidence that the neuroprotective effects of CNTF in vitro and in vivo involve the JAK-1/STAT3 and PI3K signaling pathways. In addition, it has been well documented that CNTF could modulate brain plasticity by promoting neurogenesis (Emsley and Haag, 2003; Chen et al., 2007; Yang et al., 2008; Müller et al., 2009). Whether prevention of AD phenotype resulting from continuous CNTF delivery in $\mathrm{Tg}^{\mathrm{CNTF}}$ mice involves enhanced neurogenesis requires additional investigation. Although it is unlikely that CNTF could "cure" AD at advanced stages of neuronal loss, our data strongly suggest that CNTF delivery can prevent synaptic and neuronal degeneration and halt cognitive decline.

Although potent effects with several NTFs have been reported in animal models, clinical studies did not keep up the promise, most likely because of poor delivery of the therapeutic factor to the site of interest (Thoenen and Sendtner, 2002). NTFs do not pass the blood-brain barrier, have very short half lives, and can induce severe side effects when applied systemically. One way to overcome these hurdles is with cellular implants genetically modified ex vivo to produce and deliver NTFs directly into the CNS (Tuszinski, 2007). Cell encapsulation using alginate bead technology eliminates the need for chronic immunosuppression of the host and provides safe and long-term drug release.

Indeed, ex vivo gene therapy designed to increase the concentration of neuroprotective factors in the brain resulted in therapeutic improvement in several preclinical models of neurodegenerative diseases (Hemming et al., 2007; Spencer et al., 2008). Such approaches have also been investigated in clinical trials and have demonstrated significant benefits for patients (Tobias et al., 2003; Tuszinski et al., 2005; Sieving et al., 2006). For clinical use, NTF administration must be delivered centrally in appropriate quantities to effectively stimulate neurons over a prolonged time period and to avoid intolerable side effects (Nagahara et al., 2009). A recent study showed that a transducible form of CNTF rescued mice from infused fibrillar $\mathrm{A} \beta$ (Qu et al., 2008). However, the doses of CNTF were high (i.e., 100 $\left.\mu \mathrm{g} \cdot \mathrm{kg}^{-1} \cdot \mathrm{d}^{-1}\right)$, and only short-term treatment effects were investigated. Currently, no data are available concerning the potential toxic effects of long-term and peripheral administration of high doses of this compound. Peripheral administration of CNTF is likely to induce inadequate stimulation of nontargeted systems (Tuszinski, 2007). Thus, the use of encapsulated cell implants provides the advantages of in situ targeted production of NTFs, therefore reducing the dose requirement.

It has been suggested that intraventricular infusions of NTFs fail to reach most neurons, thereby limiting this strategy of delivery and favoring an intraparenchymal delivery (Kordover et al., 1999). Interestingly, our experiments demonstrated similar efficacy of CNTF through engraftment of CNTF-secreted cells in the lateral ventricle or in the subhippocampal region. Thus, as recently described for BDNF delivery using lentiviral expression (Nagahara et al., 2009), our CNTF delivery approach could be scaled up to the size of human brain, broadly increasing the resistance of neurons throughout hippocampus and associated cortical areas during CNTF diffusion and/or transport.

In summary, our findings clearly demonstrate that continuous in situ delivery of CNTF through implantation of alginate microcapsules abolishes synaptic and behavioral impairments in mouse models of AD. The potency of CNTF presented here provides a rational for exploring its clinical efficiency. Finally, longlasting in situ delivery to maintain appropriate levels of neuroprotective factors during and shortly after the prodromal phase in $\mathrm{AD}$ patients warrants additional investigations as a potential nonviral therapeutic approach to delay this devastating disease.

\section{References}

Allen SJ, Dawbarn D (2006) Clinical relevance of the neurotrophins and their receptors. Clin Sci 110:175-191.

Almeida CG, Tampellini D, Takahashi RH, Greengard P, Lin MT, Snyder EM, Gouras GK (2005) Beta-amyloid accumulation in APP mutant neurons reduces PSD-95 and GluR1 in synapses. Neurobiol Dis 20:187-198.

Blesch A (2006) Neurotrophic factors in neurodegeneration. Brain Pathol 16:295-303.

Chen H, Tung YC, Li B, Iqbal K, Grundke-Iqbal I (2007) Trophic factors counteract elevated FGF-2-induced inhibition of adult neurogenesis. Neurobiol Aging 28:1148-1162.

Dahlgren KN, Manelli AM, Stine WB Jr, Baker LK, Krafft GA, LaDu MJ (2002) Oligomeric and fibrillar species of amyloid- $\beta$ peptides differentially affect neuronal viability. J Biol Chem 277:32046-32053.

Duff E, Baile CA (2003) Ciliary neurotrophic factor: a role in obesity? Nutr Rev 61:423-426.

Emerich DF, Thanos CG (2006) Intracompartmental delivery of CNTF as therapy for Huntington's disease and retinitis pigmentosa. Curr Gene Ther 6:147-159.

Emerich DF, Winn SR, Lindner MD (1996) Continued presence of intrastriatal but not intraventricular polymer-encapsulated PC12 cells is required for alleviation of behavioral deficits in Parkinsonian rodents. Cell Transplant 5:589-596.

Emsley JG, Hagg T (2003) Endogenous and exogenous ciliary neurotrophic factor enhances forebrain neurogenesis in adult mice. Exp Neurol 183:298-310.

Fifre A, Sponne I, Koziel V, Kriem B, Yen Potin FT, Bihain BE, Olivier JL, Oster T, Pillot $\mathrm{T}$ (2006) Microtubule-associated protein MAP1A, MAP1B, and MAP2 proteolysis during soluble amyloid beta-peptideinduced neuronal apoptosis. Synergistic involvement of calpain and caspase-3. J Biol Chem 281:229-240.

Florent S, Malaplate-Armand C, Youssef I, Kriem B, Koziel V, Escanyé MC, Fifre A, Sponne I, Leininger-Muller B, Olivier JL, Pillot T, Oster T (2006) Docosahexaenoic acid prevents neuronal apoptosis induced by soluble amyloid- $\beta$ oligomers. J Neurochem 96:385-395.

Frim DM, Uhler TA, Galpern WR, Beal MF, Breakefield XO, Isacson O (1994) Implanted fibroblasts genetically engineered to produce brainderived neurotrophic factor prevent 1-methyl-4-phenylpyridinium toxicity to dopaminergic neurons in the rat. Proc Natl Acad Sci U S A 91:5104-5108.

Garza JC, Guo M, Zhang W, Lu XY (2008) Leptin increases adult hippocampal neurogenesis in vivo and in vitro. J Biol Chem 283:18238-18247.

Hagg T (2009) From neurotransmitters to neurotrophic factors to neurogenesis. Neuroscientist 15:20-27. 
Hemming ML, Patterson M, Reske-Nielsen C, Lin L, Isacson O, Selkoe DJ (2007) Reducing amyloid plaque burden via ex vivo gene delivery of an Abeta degrading protease: a novel therapeutic approach to Alzheimer disease. PLoS Med 4:e262.

Hsiao K, Chapman P, Nilsen S, Eckman C, Harigaya Y, Younkin S, Yang F, Cole G (1996) Correlative memory deficits, Abeta elevation, and amyloid plaques in transgenic mice. Science 274:99-102.

Kawarabayashi T, Younkin LH, Saido TC, Shoji M, Ashe KH, Younkin SG (2001) Age-dependent changes in brain, CSF, and plasma amyloid $\beta$ protein in the Tg2576 transgenic mouse model of Alzheimer's disease. J Neurosci 21:372-381.

Kawarabayashi T, Shoji M, Younkin LH, Wen-Lang L, Dickson DW, Murakami T, Matsubara E, Abe K, Ashe KH, Younkin SG (2004) Dimeric amyloid $\beta$ protein rapidly accumulates in lipid rafts followed by apolipoprotein $\mathrm{E}$ and phosphorylated tau accumulation in the Tg2576 mouse model of Alzheimer's disease. J Neurosci 24:3801-3809.

Keller JN, Mark RJ, Bruce AJ, Blanc E, Rothstein JD, Uchida K, Waeg G, Mattson MP (1997) 4-Hydroxynonenal, an aldehydic product of membrane lipid peroxidation, impairs glutamate transport and mitochondrial function in synaptosomes. Neuroscience 80:685-696.

Kelly BL, Vassar R, Ferreira A (2005) Beta-amyloid-induced dynamin 1 depletion in hippocampal neurons. A potential mechanism for early cognitive decline in Alzheimer disease. J Biol Chem 280:31746-31753.

Kim HJ, Chae SC, Lee DK, Chromy B, Lee SC, Park YC, Klein WL, Krafft GA, Hong ST (2003) Selective neuronal degeneration induced by soluble oligomeric amyloid beta-protein. FASEB J 17:118-120.

Kishima H, Poyot T, Bloch J, Dauguet J, Condé F, Dollé F, Hinnen F, Pralong W, Palfi S, Déglon N, Aebischer P, Hantraye P (2004) Encapsulated GDNF-producing C2C12 cells for Parkinson's disease: a pre-clinical study in chronic MPTP-treated baboons. Neurobiol Dis $16: 428-439$

Klafki HW, Staufenbiel M, Kornhuber J, Wiltfang J (2006) Therapeutic approaches to Alzheimer's disease. Brain 129:2840-2855.

Kokubo H, Kayed R, Glabe CG, Yamaguchi H (2005) Soluble Abeta oligomers ultrastructurally localize to cell processes and might be related to synaptic dysfunction in Alzheimer's disease brain. Brain Res 1031:222-228.

Kordower JH, Isacson O, Emerich DF (1999) Cellular delivery of trophic factors for the treatment of Huntington's disease: is neuroprotection possible? Exp Neurol 159:4-20.

Kriem B, Sponne I, Fifre A, Malaplate-Armand C, Lozac'h-Pillot K, Koziel V, Yen-Potin FT, Bihain B, Oster T, Olivier JL, Pillot T (2005) Cytosolic phospholipase A2 mediates neuronal apoptosis induced by soluble oligomers of the amyloid-beta peptide. FASEB J 19:85-87.

Lacor PN, Buniel MC, Chang L, Fernandez SJ, Gong Y, Viola KL, Lambert MP, Velasco PT, Bigio EH, Finch CE, Krafft GA, Klein WL (2004) Synaptic targeting by Alzheimer's-related amyloid $\beta$ oligomers. J Neurosci 24:10191-10200.

Longo FM, Massa SM (2004) Neuroprotective strategies in Alzheimer's disease. NeuroRx 1:117-127.

Malaplate-Armand C, Florent-Béchard S, Youssef I, Koziel V, Sponne I, Kriem B, Leininger-Muller B, Olivier JL, Oster T, Pillot T (2006) Soluble oligomers of amyloid-beta peptide induce neuronal apoptosis by activating a cPLA2-dependent sphingomyelinase-ceramide pathway. Neurobiol Dis 23:178-189.

McLaurin J, Kierstead ME, Brown ME, Hawkes CA, Lambermon MH, Phinney AL, Darabie AA, Cousins JE, French JE, Lan MF, Chen F, Wong SS, Mount HT, Fraser PE, Westaway D, St George-Hyslop P (2006) Cyclohexanehexol inhibitors of Abeta aggregation prevent and reverse Alzheimer phenotype in a mouse model. Nat Med 12:801-808.

Morris R (1984) Development of a water-maze procedure for studying spatial learning in the rat. J Neurosci Methods 11:47-60.

Mucke L, Masliah E, Yu GQ, Mallory M, Rockenstein EM, Tatsuno G, Hu K, Kholodenko D, Johnson-Wood K, McConlogue L (2000) High-level neuronal expression of $\mathrm{A} \beta_{1-42}$ in wild-type human amyloid protein precursor transgenic mice: synaptotoxicity without plaque formation. J Neurosci 20:4050-4058.

Müller S, Chakrapani BP, Schwegler H, Hofmann HD, Kirsch M (2009) Neurogenesis in the dentate gyrus depends on ciliary neurotrophic factor and signal transducer and activator of transcription 3 signaling. Stem Cells 27:431-441.
Nagahara AH, Merrill DA, Coppola G, Tsukada S, Schroeder BE, Shaked GM, Wang L, Blesch A, Kim A, Conner JM, Rockenstein E, Chao MV, Koo EH, Geschwind D, Masliah E, Chiba AA, Tuszynski MH (2009) Neuroprotective effects of brain-derived neurotrophic factor in rodent and primate models of Alzheimer's disease. Nat Med 15:331-337.

Pillot T, Drouet B, Queillé S, Labeur C, Vandekerchkhove J, Rosseneu M, Pinçon-Raymond M, Chambaz J (1999) The non-fibrillar amyloid $\beta$-peptide induces apoptotic neuronal cell death: involvement of its C-terminal fusogenic domain. J Neurochem 73:1626-1634.

Puzzo D, Privitera L, Leznik E, Fà M, Staniszewski A, Palmeri A, Arancio O (2008) Picomolar amyloid- $\beta$ positively modulates synaptic plasticity and memory in hippocampus. J Neurosci 28:14537-14545.

Qu HY, Zhang T, Li XL, Zhou JP, Zhao BQ, Li Q, Sun MJ (2008) Transducible P11-CNTF rescues the learning and memory impairments induced by amyloid-beta peptide in mice. Eur J Pharmacol 594:93-100.

Read TA, Sorensen DR, Mahesparan R, Enger PO, Timpl R, Olsen BR, Hjelstuen MH, Haraldseth O, Bjerkvig R (2001) Local endostatin treatment of gliomas administered by microencapsulated producer cells. Nat Biotechnol 19:29-34.

Rowan MJ, Klyubin I, Wang Q, Hu NW, Anwyl R (2007) Synaptic memory mechanisms: Alzheimer's disease amyloid $\beta$-peptide-induced dysfunction. Biochem Soc Trans 35:1219-1223.

Sarter M, Bodewitz G, Stephens DN (1988) Attenuation of scopolamineinduced impairment of spontaneous alternation behavior by antagonist but not inverse agonist and agonist betacarbolines. Psychopharmacology 94:491-495.

Scheff SW, Price DA, Schmitt FA, DeKosky ST, Mufson EJ (2007) Synaptic alterations in CA1 in mild Alzheimer disease and mild cognitive impairment. Neurology 68:1501-1508.

Selkoe DJ (2002) Alzheimer's disease is a synaptic failure. Science 298:789-791.

Selkoe DJ (2004) Alzheimer disease: mechanistic understanding predicts novel therapies. Ann Intern Med 140:627-638.

Sieving PA, Caruso RC, Tao W, Coleman HR, Thompson DJ, Fullmer KR, Bush RA (2006) Ciliary neurotrophic factor (CNTF) for human retinal degeneration: phase I trial of CNTF delivered by encapsulated cell intraocular implants. Proc Natl Acad Sci U S A 103:3896-3901.

Spencer B, Marr RA, Rockenstein E, Crews L, Adame A, Potkar R, Patrick C, Gage FH, Verma IM, Masliah E (2008) Long-term neprilysin gene transfer is associated with reduced levels of intracellular Abeta and behavioral improvement in APP transgenic mice. BMC Neurosci 9:109.

Sponne I, Fifre A, Drouet B, Klein C, Koziel V, Pinçon-Raymond M, Olivier JL, Chambaz J, Pillot T (2003) Apoptotic neuronal cell death induced by the non-fibrillar amyloid- $\beta$ peptide proceeds through an early ROS-dependent cytoskeleton perturbation. J Biol Chem 278: 3437-3445.

Sponne I, Fifre A, Koziel V, Oster T, Olivier JL, Pillot T (2004) Membrane cholesterol interferes with neuronal apoptosis induced by soluble oligomers but not fibrils of amyloid- $\beta$ peptide. FASEB J 18:836-838

Thoenen H, Sendtner M (2002) Neurotrophins: from enthusiastic expectations through sobering experiences to rational therapeutic approaches. Nat Neurosci 5:1046-1050.

Tobias CA, Shumsky JS, Shibata M, Tuszynski MH, Fischer I, Tessler A, Murray M (2003) Delayed grafting of BDNF and NT-3 producing fibroblasts into the injured spinal cord stimulates sprouting, partially rescues axotomized red nucleus neurons from loss and atrophy, and provides limited regeneration. Exp Neurol 184:97-113.

Tuszynski MH (2007) Nerve growth factor gene therapy in Alzheimer disease. Alzheimer Dis Assoc Disord 21:179-189.

Tuszynski MH, Smith DE, Roberts J, McKay H, Mufson E (1998) Targeted intraparenchymal delivery of human NGF by gene transfer to the primate basal forebrain for 3 months does not accelerate beta-amyloid plaque deposition. Exp Neurol 154:573-582.

Tuszynski MH, Thal L, U HS, Pay MM, Blesch A, Conner J, Vahlsing HL (2002) Nerve growth factor gene therapy for Alzheimer's disease. J Mol Neurosci 19:207.

Tuszynski MH, Thal L, Pay M, Salmon DP, U HS, Bakay R, Patel P, Blesch A, Vahlsing HL, Ho G, Tong G, Potkin SG, Fallon J, Hansen L, Mufson EJ, Kordower JH, Gall C, Conner J (2005) A phase 1 clinical trial of nerve growth factor gene therapy for Alzheimer disease. Nat Med 11:551-555. 
Twiss JL, Chang JH, Schanen NC (2006) Pathophysiological mechanisms for actions of the neurotrophins. Brain Pathol 16:320-332.

Vicario-Abejón C, Owens D, McKay R, Segal M (2002) Role of neurotrophins in central synapse formation and stabilization. Nat Rev Neurosci 3:965-974.

Walsh DM, Klyubin I, Fadeeva JV, Cullen WK, Anwyl R, Wolfe MS, Rowan MJ, Selkoe DJ (2002) Naturally secreted oligomers of amyloid $\beta$ protein potently inhibited hippocampal long-term potentiation in vivo. Nature 416:535-539.

Westerman MA, Cooper-Blacketer D, Mariash A, Kotilinek L, Kawarabayashi T, Younkin LH, Carlson GA, Younkin SG, Ashe KH (2002) The relationship between Abeta and memory in the $\operatorname{Tg} 2576$ mouse model of Alzheimer's disease. J Neurosci 22:1858-1867.

White JA, Manelli AM, Holmberg KH, Van Eldik LJ, Ladu MJ (2005) Dif- ferential effects of oligomeric and fibrillar amyloid- $\beta 1-42$ on astrocytesmediated inflammation. Neurobiol Dis 18:459-465.

Yankner BA, Lu T (2009) Amyloid beta-protein toxicity and the pathogenesis of Alzheimer disease. J Biol Chem 284:4755-4759.

Yasuhara T, Shingo T, Muraoka K, Kameda M, Agari T, Wen Ji Y, Hayase H, Hamada H, Borlongan CV, Date I (2005) Neurorescue effects of VEGF on a rat model of Parkinson's disease. Brain Res 1053:10-18.

Young JW, Sharkey J, Finlayson K (2009) Progressive impairment in olfactory working memory in a mouse model of mild cognitive impairment. Neurobiol Aging 30:1430-1443.

Youssef I, Florent-Béchard S, Malaplate-Armand C, Koziel V, Bihain B, Olivier JL, Leininger-Muller B, Kriem B, Oster T, Pillot T (2008) $\mathrm{N}$-truncated amyloid-beta oligomers induce learning impairment and neuronal apoptosis. Neurobiol Aging 29:1319-1333. 